\title{
Media Pembelajaran Videoscribe-Hots Bermuatan IPA Pada Topik Struktur Dan Fungsi Bagian Tumbuhan Kelas IV SD
}

\section{Luh Gede Ria Andika Putri1*, I Gusti Ngurah Japa², Putu Nanci Riastini3}

\author{
1,2,3 Program Studi Pendidikan Guru Sekolah Dasar, Universitas Pendidikan Ganesha, Singaraja, Indonesia
}

\section{ART ICLE INF O}

Article history:

Received August 23, 2021

Revised August 25, 2021

Accepted October 30, 2021

Available online December 25, 2021

Kata Kunci:

Media, HOTS, IPA

Keywords:

Media, HOTS, IPA

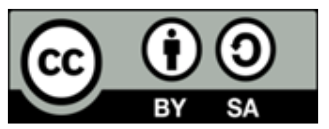

This is an open access article under the CC BY-SA license.

Copyright (ㅇ) 2021 by Author. Published by Universitas Pendidikan Ganesha.

\begin{abstract}
A B S T R A K
Kurangnya ketersediaan media pembelajaran pada pembelajaran daring berdampak kepada rendahnya semangat belajar siswa. Hal tersebut diperparah dengan materi pada muatan pelajaran IPA yang ada pada buku siswa masih kurang lengkap. Penelitian ini bertujuan merancang video pembelajaran berbasis Videoscribe pada topik struktur dan fungsi bagian tumbuhan kelas IV SD berkategori valid. Penelitian ini berjenis $R n D$ (pengembangan), menggunakan model penelitian ADDIE. Subjek penelitian ini terdiri dari 2 orang ahli materi, 2 orang ahli media, 2 orang ahli desain pembelajaran, 2 orang praktisi, dan 10 orang siswa kelas IV SD. Penelitian ini menggunakan metode pengumpulan data berupa instrumen penilaian rating scale. Data kemudian dianalisis menggunakan Indeks Validitas Aiken's untuk mengetahui tingkat validitasnya. Berdasarkan hasil analisis uji ahli diperoleh rentangan Indeks Validitas Aiken's adalah $0,8-1$ yang berada pada $V \geq 0,8$ dengan kriteria validitas tinggi, respon praktisi sebesar $97 \%$ berkategori sangat baik, dan respon siswa sebesar $97 \%$ berkategori sangat baik. Berdasarkan analisis tersebut media video pembelajaran berbasis videoscribe pada topik struktur dan fungsi bagian tumbuhan kelas IV SD layak untuk digunakan dalam proses pembelajaran. Implikasi penelitian pengembangan yang dilakukan yaitu dengan adanya pengembangan media pembelajaran VideoScribe-HOTS ini diharapkan mampu membantu guru dalam menyampaikan materi pelajaran khususnya pada muatan pelajaran IPA topik struktur dan fungsi bagian tumbuhan kelas IV.
\end{abstract}

\section{A B S T R A C T}

The character strengthening values is not only related to politeness but can also be associated with awareness and tax compliance. Tax awareness is still relatively low so that it is impacted on low tax compliance. This study aims to describe the inclusion of tax awareness in learning Indonesian (MPK) as a strengthening the nationalist character, so that, the students have a positive attitude towards the Indonesian and tax awareness as a form of supporting the nationalist character (love the country). This research is a descriptive research with a qualitative approach. The subjects of this study were 130 students of Undiksha (MPK study group). This study used the documentation method with research instruments in the form of documentation guidelines and questionnaires. The research data were analyzed using descriptive qualitative methods, which included data collection, data reduction, data presentation, and data verification. The results of this study indicated that some students did not know the definition of tax, taxpayer, the impact of not paying taxes, tax penalty and tax benefits that impacted on tax awareness. This tax awareness inclusion research could strengthen the nationalist character of the students, fostering tax awareness and a positive attitude as Indonesian speakers. This proves that the inclusion of tax awareness in MPK learning in university is important and must be continued, so that it can strengthen the national character values.

\section{PENDAHULUAN}

Media merupakan berbagai jenis komponen dalam lingkungan siswa yang dapat merangsang untuk pembelajaran (Nahdi \& Jatisunda, 2020; Rusydiyah et al., 2021). Berdasarkan beberapa pengertian mengenai media tersebut, dapat disimpulkan bahwa media merupakan suatu komponen atau alat yang digunakan sebagai perantara komunikasi antara dua orang atau lebih dalam memperjelas suatu hal (Friman, 2020; Irmansyah et al., 2020). Dalam proses pembelajaran, media tentu memiliki peran yang sangat penting, karena pada hakekatnya proses pembelajaran merupakan komunikasi 2 arah antara 
pendidik dan peserta didik, media dalam proses pembelajaran sering disebut dengan media pembelajaran (Jampel et al., 2018; Novita et al., 2019). Media pembelajaran merupakan media yang digunakan untuk mempermudah proses pembelajaran yang dilakukan oleh pendidik dalam penyampaian materi kepada peserta didik, media pembelajaran mampu merangsang kemampuan berpikir, minat dan motivasi belajar siswa, sehingga kegiatan pembelajaran menjadi lebih bermakna dan kondusif (Adi \& Widodo, 2018; Atmojo et al., 2020). Keberadaan media pembelajaran dalam pembelajaran sangat berpengaruh terhadap kualitas pembelajaran, melalui adanya media mampu meningkatkan pemahaman seseorang dan mengurangi kesalahpahaman mengenai hal atau materi yang dibahas, serta mampu meningkatkan semangat belajar siswa (Angraini, 2017; MS et al., 2017). Sehingga dengan demikian guru sebagai seorang pendidik diharapkan mampu menyediakan media pembelajaran disetiap pembelajaran, agar proses pembelajaran yang dilakukan dapat memberikan makna bagi peserta didik, mengingat media memiliki fungsi yang sangat vital dalam pembelajaran.

Akan tetapi fakta di lapangan menunjukkan fakta yang berbeda, dimana dalam prosesnya pembelajaran yang dilakukan cenderung belum memanfaatkan media pembelajaran secara maksimal. Padahal dalam kurikulum 2013 penerapan media pembelajaran merupakan hal yang sangat penting, karena dalam proses pembelajaran di dalam kurikulum 2013 guru bertindak sebagai fasilitator yang membantu peserta didik menemukan konsep atau pengetahuannya secara mandiri. Selain hal tersebut, kurikulum 2013 juga menuntut peserta didik memiliki kemampuan berpikir tingkat tinggi atau sering disebut dengan HOTS. Salah satu penyebab hal tersebut dapat terjadi berdasarkan hasil wawancara serta observasi yang dilakukan pada saat pelaksanaan PLPbD tahun 2020 di SD Negeri 3 Munduktemu adalah kurangnya pemahaman guru dalam menyusun media pembelajaran yang inovatif, khususnya pada proses pembelajaran berbasis HOTS. Hal ini semakin diperparah dengan kurang ketersediaannya media pembelajaran di sekolah yang mampu mencakup serta membantu dalam melaksanakan proses pembelajaran berbasis HOTS. Guru diharapkan mampu menyediakan media pembelajaran inovatif berbasis pembelajaran HOTS sebagai usaha dalam meningkatkan semangat belajar peserta didik, terlebih lagi dalam kondisi pembelajaran dalam jaringan (daring) saat ini. Karena, apabila hal ini terus dibiarkan maka akan berdampak kepada penurunan semangat belajar dari peserta didik, sehingga proses pembelajaran tidak akan lagi memberikan manfaat kepada peserta didik khususnya pada aspek kemampuan berpikir tingkat tinggi (HOTS) siswa.

Salah satu solusi yang dapat dilakukan dalam mengatasi permasalahan diatas adalah dengan merancang sebuah media pembelajaran berbasis HOTS yang mampu meningkatkan semangat belajar siswa, khususnya pada muatan pembelajaran IPA. Salah satu jenis media yang tepat dan mampu meningkatkan semangat belajar siswa serta mampu terintegrasi dengan pembelajaran berbasis HOTS adalah media video pembelajaran menggunakan aplikasi videoscribe. Solusi ini didukung oleh beberapa penelitian, dimana hasil dari penelitian tersebut bersifat relevan. Media pembelajaran Sparkol VideoScribe memiliki beberapa kelebihan seperti dapat menarik perhatian siswa saat kegiatan belajar sehingga materi bisa tersalurkan lebih efektif, serta berdasarkan uji kelayakan isi, kebahsan, penyajian diperoleh persentase 80\% dengan kriteria baik (Latifah et al., 2020). Data tes hasil belajar (pre-test) secara keseluruhan diperoleh hasil persentase sebesar 75\%, maka berdasarkan kriteria yang ditentukan dapat dijelaskan bahwa media video pembelajaran mengenai mata pelajaran IPA tentang sifat dan perubahan wujud benda kelas IV SDN Merjosari 5 Malang termasuk kategori cukup efektif (Kurniawan et al., 2018). Penggunaan media video pembelajaran mampu meningkatkan pemahaman materi siswa secara signifikan pada topik Pencemaran Dan Kerusakan Lingkungan (Mutia et al., 2018). Terdapat pengaruh positif pada pembelajaran IPA yang menggunakan media video dibandingkan dengan pembelajaran IPA yang menggunakan media gambar terhadap motivasi belajar dan hasil belajar kognitif pembelajaran IPA (Pebriani, 2017). Kemampuan berpikir tingkat tinggi siswa yang dibelajarkan dengan media video pembelajaran lebih baik dibandingkan dengan siswa yang dibelajarkan dengan media power point (Gowasa et al., 2019).

Penggunaan media video pada mata pelajaran IPA di kelas III SD Inpres Lanraki II memberikan pengaruh positif terhadap peningkatan semangat belajar siswa, ini dibuktikan dengan hasil pengamatan yang telah dilakukan baik itu kepada siswa maupun kepada guru disetiap pertemuan mengalami peningkatan (Pagarra \& Idrus, 2018). Video pembelajaran IPA tema konservasi gajah berkarakter peduli lingkungan yang dikembangkan dinilai oleh siswa menarik untuk digunakan dalam pembelajaran (Yudiyanto et al., 2020). Terdapat perbedaan yang signifikan hasil belajar siswa antara sebelum dan sesudah menggunakan video pembelajaran (Nanda et al., 2017). Terdapat pengaruh positif dan signifikan antara penggunaan media pembelajaran audio visual video terhadap hasil belajar sub tema 1 keberagaman budaya bangsaku (Novita et al., 2019). Video pembelajaran bisa digunakan siswa untuk membantu proses belajarnya dari rumah sehingga dengan mudah memahami konsep IPA dasar (Jundu et al., 2020). Namun, masih terdapat beberapa kekurangan pada pengembangan media video pembelajaran 
yang dilakukan sebelumnya, salah satunya adalah penggunaan dubbing suara serta animasi yang cenderung masih bersifat monoton. Pada pengemangan media video pembelajaran kali ini akan mengoptimalkan aspek-aspek yang dirasa masih kurang dari pengembangan sebelumnya, serta mengintegrasikan dengan keterampilan berfikir tingkat tinggi (HOTS).

Produk yang dihasilkan pada penelitian ini yaitu berupa media pembelajaran VideoScribe-HOTS pada muatan pelajaran IPA topik Struktur dan Fungsi Bagian Tumbuhan. Media pembelajaran ini dirancang guna untuk meningkatkan semangat belajar dan pemahaman siswa mengenai materi yang dijelaskan. Berikut merupakan karakteristik produk yang dikembangkan, yaitu pada slide pendahuluan media pembelajaran VideoScribe-HOTS, terdiri atas judul materi yang dikembangkan, identitas diri, logo, menyapa siswa, menampilkan KD, Indikator, dan Tujuan Pembelajaran, pada slide isi terdiri atas materi struktur dan fungsi bagian-bagian tumbuhan, pada slide penutup terdiri atas simpulan materi yang dijelaskan. Media pembelajaran yang dikembangkan memuat HOTS. Adanya memuat HOTS ditandai dengan adanya pemberian pertanyaan disetiap penjelasan materi guna mengembangkan keterampilan berfikir tingkat tinggi siswa dan meningkatkan pemahaman mengenai materi yang dijelaskan. Berisi materi pelajaran Muatan IPA Topik Struktur dan Fungsi Bagian Tumbuhan Kelas IV SD. Media pembelajaran VideoScribe-HOTS dilengkapi dengan penjelasan materi yang disertai dengan teks dan gambar animasi yang didapatkan dari berbagai sumber dan dokumentasi pribadi yang ditata semenarik mungkin serta penjelasan materi berupa audio mengenai materi yan disampaikan. Hal ini bertujuan untuk membantu siswa agar lebih memahami materi yang ditampilkan, serta terdapat latihan soal diakhir video pembelajaran, bertujuan sebagai feedback untuk mengukur tingkat pemahaman siswa mengenai materi yang ditelah dipelajari.

Tujuan pengembangan kali ini adalah menghasilkan prototype media pembelajaran videoscribe berbasis HOTS pada muatan pelajaran IPA topik struktur dan fungsi bagian tumbuhan di kelas IV SD, serta mengetahui validitas dari media video pembelajaran yang telah dikembangkan. Secara teoritis, penelitian ini diharapkan mampu menambah khasanah pengetahuan dan wawasan pembaca mengenai media pembelajaran yang memuat HOTS serta mampu digunakan sebagai referensi oleh peneliti lainnya yang melakukan penelitian mengenai pengembangan media pembelajaran VideoScribe-HOTS pada muatan pelajaran IPA topik Struktur dan Fungsi Bagian Tumbuhan di Kelas IV SD. Kemudian, secara praktis media pembelajaran VideoScribe-HOTS pada muatan pelajaran IPA topik Struktur dan Fungsi Bagian Tumbuhan ini diharapkan mampu meningkatan minat dan motivasi belajar siswa, sehingga siswa mampu aktif, belajar yang bermakna, dan dapat turut serta terlibat dalam penggunaan media.

\section{METODE}

Penelitian ini termasuk kedalam jenis penelitian $R n D$ (pengembangan) yang berorientasi kepada produk berupa media pembelajaran berjenis video pembelajaran. Model yang digunakan pada penelitian pengembangan ini adalah model pengembangan ADDIE. 1. berikut ini. Pemilihan model ini didasarkan pada tujuan dari penelitian yang dilakukan yaitu menghasilkan suatu produk berupa media pembelajaran VideoScribe-HOTS. Model ADDIE merupakan suatu model yang menekankan pada adanya hubungan antara masing-masing komponen yang saling berinteraksi satu sama lain sesuai dengan fase yang ada (Mayub et al., 2020; Nahdi \& Jatisunda, 2020). Penelitian kali ini dilakukan di SD Negeri 3 Munduktemu. Penelitian ini menggunakan metode pengumpulan data berupa kuesionr atau angket. Subjek pada penelitian ini terdiri dari 2 orang ahli materi, 2 orang ahli media, 2 orang ahli desain pembelajaran, 2 orang praktisi, dan 10 orang siswa kelas IV SD. Analisis data yang digunakan dalam penelitian ini menggunakan dua jenis analisis yakni analisis statistik deskriptif kualitatif dan analisis statistik deskriptif kuantitatif menggunakan rumus inddeks validitas Aiken's. Data yang dihasilkan melalui analisis deskriptif kualitatif berupa data deskripsi atau kata-kata, dan data yang dihasilkan melalui analisis deskriptif kuantitatif adalah tingkat validitas dari media itu sendiri. Secara garis besar, adapun desain pada penelitian dan desain uji coba pada penelitian kali ini dapat dilihat pada Gambar 1 dan Gambar 2.

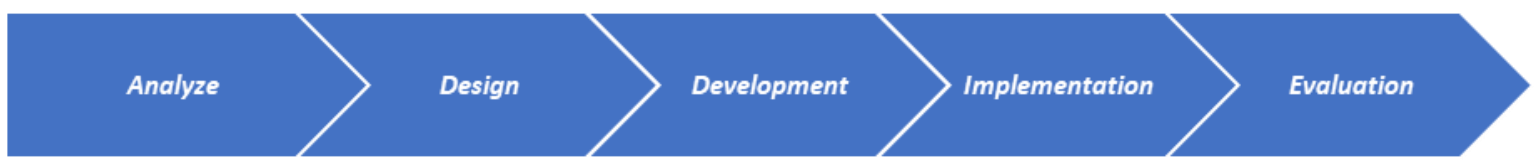

Dimodifikasi dari (Haryani et al., 2017)

Gambar 1. Desain Penelitian 
Media pembelajaran

VideoScribe-HOTS pada muatan

pelajaran IPA topik

Struktur dan Fungsi

Bagian Tumbuhan
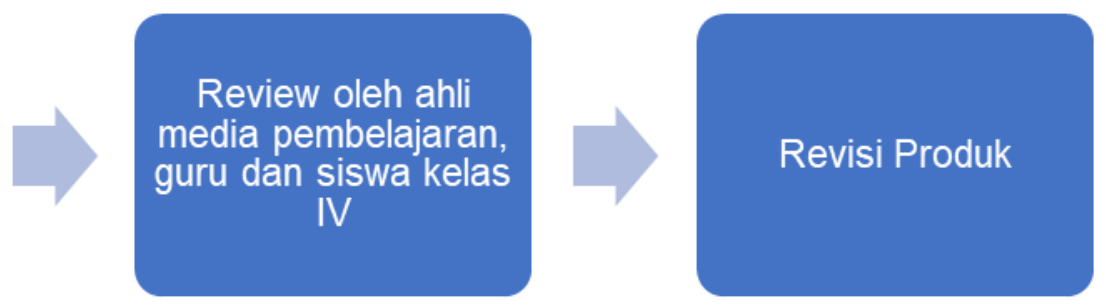

Dimodifikasi dari (Pratama et al., 2020)

Gambar 2. Desain Uji Coba Produk

Adapun tahapan pengembangan pada penelitian kali ini terdiri dari 3 tahapan, yakni tahap Analyze (Analisis), tahap Design (perancangan), dan tahap Development (Pengembangan). Tahap implementasi dan evaluasi pada penelitian kali ini tidak dilaksanakan mengingat situasi dunia yang sedang dilanda pandemi Covid-19. Tahap Analyze (Analisis) terdiri dari beberapa aspek yang akan di analisis pada tahapan ini, yakni analisis kebutuhan, analisis kurikulum, analisis buku guru dan buku siswa, analisis karakteristik siswa, dan analisis syarat pembuatan media (Purnami et al., 2021; Yusup, 2018). Analisis kebutuhan dilakukan melalui kegiatan observasi dan wawancara yang dilaksanakan pada saat pelaksanaan PLPbD 2020 dengan guru kelas IV SD Negeri 3 Munduktemu. Analisis kurikulum dilakukan dengan mengkaji isi silabus dan RPP untuk mengetahui KI dan KD muatan pelajaran IPA di kelas IV. Analisis buku guru dan buku siswa, dilakukan untuk mengetahui sejauh mana cakupan materi muatan IPA yang ada pada buku, sehingga dapat diketahui materi yang perlu dikembangkan. Analisis karakteristik siswa dalam mengikuti pembelajaran di kelas, analisis ini dilakukan dengan cara melakukan pengamatan atau observasi pada saat pelaksanaan PLPbD 2020 di SD Negeri 3 Munduktemu. Analisis syarat pembuatan media yang dilakukan sehingga mampu mengembangkan media yang baik dan relevan.

Tahap Design (perancangan), pada tahap ini dilakukan perancangan media pembelajaran VideoScribe-HOTS pada muatan pelajaran IPA topik Struktur dan Fungsi Bagian Tumbuhan Kelas IV SD. Tahap ini diawali dengan menentukan KD (Kompetensi Dasar) dan Indikator dari topik yang akan dibahas. Tahap selanjutnya yaitu membuat rancangan awal berupa naskah dan Storyboard. Setelah rancangan awal selesai, tahap selanjutnya yaitu melakukan konsultasi dengan dosen pembimbing guna mendapat masukan/saran sehingga dapat dilakukan perbaikan. Tahap selanjutnya yaitu pembuatan produk. Setelah produk awal selesai, kemudian dilakukan konsultasi dengan dosen pembimbing guna memperoleh masukan/saran sehingga dapat dilakukan perbaikan media. Setelah produk selesai diperbaiki selanjutnya yaitu pelaksanaan tahap development (pengembangan). Tahap Development (pengembangan), sesuai dengan namanya dilakukan kegiatan pengembangan media pembelajaran VideoScribe-HOTS berdasarkan rancangan yang telah dikonsultasikan dan mendapat kritik/saran dari dosen pembimbing. Jika media telah selesai dikembangkan, tahap selanjutnya yaitu melakukan uji media pembelajaran meliputi uji ahli oleh ahli media dan pembelajaran IPA guna untuk menguji media yang telah dikembangkan. Uji ahli dilakukan dengan metode kuesioner yaitu memberikan lembar penilaian kepada dosen pembimbing dan guru kelas IV yang berisi tentang validitas media pembelajaran VideoScribe-HOTS pada muatan pelajaran IPA topik Struktur dan Fungsi Bagian Tumbuhan. Data hasil review oleh ahli dan guru kemudian dianalisis untuk mengetahui tingkat validitas media yang telah dikembangkan. Adanya masukan dan saran dalam tahap ini digunakan untuk perbaikan atau revisi terhadap media yang dikembangkan.

Subjek pada penelitian pengembangan ini terdiri dari para ahli, praktisi, dan kelompok siswa kecil. Secara spesifik subjek pada penelitian ini teridri dari 2 orang dosen dengan spesifikasi minimal sarjana (S1) Pendidikan Guru Sekolah Dasar di Universitas Pendidikan Ganesha sebagai ahli materi, 2 orang dosen dengan spesifikasi minimal sarjana (S1) Pendidikan Guru Sekolah Dasar di Universitas Pendidikan Ganesha sebagai ahli media, 2 orang dosen dengan spesifikasi minimal sarjana (S1) Pendidikan Guru Sekolah Dasar di Universitas Pendidikan Ganesha sebagai ahli desain pembelajran, 2 orang praktisi yang berkopeten di bidangnya, dan 10 orang siswa kelas IV SD guna mengetahui respon dari siswa mengenai media pembelajaran yang berhasil dikembangkan. Instrumen pengumpulan data yang digunakan pada penelitian ini terdiri dari beberapa aspek penilaian, bertujuan untuk menguji validitas media pembelajaran VideoScribe-HOTS pada muatan pelajaran IPA topik Struktur dan Fungsi Bagian Tumbuhan. Penilaian media mengacu pada aspek-aspek validitas yang meliputi aspek format, isi, bahasa, praktis dan efektif. Beberapa aspek yang disebutkan digunakan sebagai acuan atau panduan dalam penyusunan kisi-kisi lembar validasi media pembelajaran VideoScribe-HOTS pada muatan 
pelajaran IPA topik Struktur dan Fungsi Bagian Tumbuhan Kelas IV SD. Adapun kisi-kisi instrument yang digunakan pada penelitian kali ini dapat dilihat pada Tabel 1,2,3,4, dan 5 .

Tabel 1. Kisi-kisi Instrumen Ahli Materi

\begin{tabular}{ccccc}
\hline No & \multirow{2}{*}{ Aspek } & Indikator & No.Butir & $\begin{array}{c}\text { Jumlah } \\
\text { Butir }\end{array}$ \\
\hline \multirow{2}{*}{1} & \multirow{2}{*}{ Pembelajaran } & Tujuan pembelajaran & $1,2,3,4$ & 4 \\
& & Penyampaian materi & 5,6 & 2 \\
\multirow{2}{*}{2} & \multirow{2}{*}{ Materi } & Kualitas memotivasi & $7,8,9$ & 3 \\
& & Relevansi materi & $10,11,12$ & 3 \\
\hline & Pemilihan materi & $13,14,15$ & 3 \\
\hline
\end{tabular}

Tabel 2. Kisi-kisi Instrumen Ahli Media

\begin{tabular}{ccccc}
\hline \multirow{2}{*}{ No } & Aspek & Indikator & No.Butir & $\begin{array}{c}\text { Jumlah } \\
\text { Butir }\end{array}$ \\
\hline \multirow{2}{*}{1} & \multirow{2}{*}{ Kualitas media } & Kualitas video yang ditampilkan & 1,2, & 2 \\
& & Kemudahan penggunaan & 3 & 1 \\
2 & Penggunaan Bahasa & Kejelasan suara dan kejelasan teks & $4,5,6$ & 3 \\
3 & Kesesuaian penyajian video & Kesesuaian video dengan karakteristik siswa & 9 & 1 \\
3 & Kejelasan Penyajian Video & Suara & 10 & 1 \\
& & Musik & 11 & 1 \\
4 & Kreativitas & Kemenarikan kreativitas dalam & 12 & 1 \\
\hline & & penyampaian materi & & $\mathbf{1 2}$ \\
\hline
\end{tabular}

Tabel 3. Kisi-kisi Instrumen Ahli Desain Pembelajaran

\begin{tabular}{|c|c|c|c|c|}
\hline No & Aspek & Indikator & No.Butir & $\begin{array}{c}\text { Jumlah } \\
\text { Butir }\end{array}$ \\
\hline \multirow{3}{*}{1} & \multirow{3}{*}{$\begin{array}{l}\text { Kualitas } \\
\text { media }\end{array}$} & Kualitas video yang ditampilkan & 1,2 , & 2 \\
\hline & & Kemudahan penggunaan & 3 & 1 \\
\hline & & Kejelasan suara dan kejelasan teks & $4,5,6$ & 3 \\
\hline \multirow{3}{*}{2} & \multirow{3}{*}{ Kesuaian } & Tujuan Pembelajaran & 7 & 1 \\
\hline & & Karakteristik Siswa & 8 & 1 \\
\hline & & Materi & 9 & 1 \\
\hline \multirow{4}{*}{3} & \multirow{3}{*}{$\begin{array}{c}\text { Kualitas } \\
\text { memotivasi }\end{array}$} & Video pembelajaran mampu memotivasi minat belajar siswa & 10 & 1 \\
\hline & & $\begin{array}{l}\text { Video pembelajaran mampu meningkatkan perhatian siswa } \\
\text { pada pembelajaran }\end{array}$ & 11 & 1 \\
\hline & & Meningkatkan pemahaman siswa terhadap materi & 12 & 1 \\
\hline & & Jumlah butir & & 12 \\
\hline
\end{tabular}

Tabel 4. Kisi-kisi Instrumen Respon Praktisi

\begin{tabular}{|c|c|c|c|c|}
\hline No & Aspek & Indikator & No.Butir & $\begin{array}{l}\text { Jumlah } \\
\text { Butir }\end{array}$ \\
\hline \multirow{3}{*}{1} & \multirow{3}{*}{ Pembelajaran } & Tujuan pembelajaran & $1,2,3$ & 3 \\
\hline & & Penyampaian materi & 4,5 & 2 \\
\hline & & Kualitas memotivasi & $6,7,8$ & 3 \\
\hline 2 & Materi & Relevansi materi & $9,10,11$ & 3 \\
\hline \multirow{2}{*}{3} & \multirow{2}{*}{ Kualitas Media } & Kualitas video yang ditampilkan & $12,13,14,15$ & 4 \\
\hline & & Kejelasan penyajian video & 16,17 & 2 \\
\hline 4 & $\begin{array}{l}\text { Kesesuaian Penyajian } \\
\text { Video }\end{array}$ & $\begin{array}{c}\text { Kesesuaian video pembelajaran dengan } \\
\text { karakteristik siswa }\end{array}$ & 18 & 1 \\
\hline 5 & Penggunaan Bahasa & Kualitas Penggunaan Bahasa & 19,20 & 2 \\
\hline & & Jumlah butir & & 20 \\
\hline
\end{tabular}


Tabel 5. Kisi-kisi Instrumen Respon Siswa

\begin{tabular}{|c|c|c|c|c|}
\hline No & Aspek & Indikator & No.Butir & $\begin{array}{l}\text { Jumlah } \\
\text { Butir }\end{array}$ \\
\hline \multirow[t]{4}{*}{1} & \multirow[t]{3}{*}{ Materi } & $\begin{array}{l}\text { Materi yang disampaikan penting diberikan kepada } \\
\text { siswa }\end{array}$ & 1 & 1 \\
\hline & & Materi disampaikan secara jelas & 2 & 1 \\
\hline & & $\begin{array}{l}\text { Siswa mampu memahami materi yang ditampilkan } \\
\text { pada video }\end{array}$ & 3 & 1 \\
\hline & & Kualitas video yang ditampilkan & $4,5,6$ & 3 \\
\hline \multirow[t]{2}{*}{2} & Kualitas video & Kemudahan penggunaan & 7 & 1 \\
\hline & & Kejelasan suara & 8 & 1 \\
\hline \multirow[t]{2}{*}{3} & Kemenarikan & Desain tampilan video pembelajaran sangat menarik & 9 & 1 \\
\hline & & Penggunaan warna yang sesuai dan beragam & 10 & 1 \\
\hline 4 & Kualitas media & Kualitas Memotivasi & 11,12 & 2 \\
\hline \multirow[t]{2}{*}{5} & Tampilan media & Penyajian video & 13,14 & 2 \\
\hline & & Jumlah butir & & 14 \\
\hline
\end{tabular}

Terdapat dua jenis teknik analisis data yang digunakan pada penelitian ini, yakni tehnik analisis statistik deskriptif kualitatif dan analisis statistik deskriptif kuantitatif. Tehnik analisis data statistik deskriptif kualitatif menghasilkan data berupa masukan, kritik dan saran akan dianalisis dan dijadikan sebagai bahan untuk memperbaiki media pembelajaran yang dikembangkan. Tehnik analisis data statistik deskriptif kuantitatif menghasilkan data berupa angka. Teknik analisis ini digunakan untuk mengolah data yang diperoleh melalui angket dalam bentuk data deskriptif. Metode analisis statistik deskriptif kuantitatif ini digunakan untuk menganalisis data berupa skor yang didapat dari lembar penilaian Media Pembelajaran VideoScribe-HOTS yang diberikan kepada ahli materi, ahli media, dan ahli desain pembelajaran untuk mendapatkan kesepakatan ahli mengenai media yang dikembangkan.

\section{HASIL DAN PEMBAHASAN}

Hasil

Penelitian pengembangan ini menghasilkan media pembelajaran VideoScribe-HOTS pada muatan pelajaran IPA topik Struktur dan Fungsi Bagian Tumbuhan Kelas IV SD yang telah teruji validitasnya. Hal ini diperoleh berdasarkan uji validitas media pembelajaran VideoScribe-HOTS pada muatan pelajaran IPA topik Struktur dan Fungsi Bagian Tumbuhan Kelas IV SD yang dilakukan oleh 2 orang ahli materi, 2 orang ahli media, 2 orang ahli desain pembelajaran, 2 orang praktisi, dan 10 orang siswa kelas IV SD. Uji validitas produk ini penting untuk dilakukan agar tingkat validitas dari media pembelajaran VideoScribeHOTS pada muatan pelajaran IPA topik Struktur dan Fungsi Bagian Tumbuhan Kelas IV SD yang dikembangkan dapat diketahui. Uji validitas produk dilaksanakan melalui beberapa tahapan, yakni uji ahli materi melalui review dari dua orang ahli materi, uji ahli media melalui review dari dua orang ahli media, uji ahli desain pembelajaran melalui review dua orang ahli desain pembelajaran, review dari dua orang praktisi yang berkompeten di bidangnya, serta review dari 10 orang siswa kelas IV SD guna mengetahui respon mengenai media yang dikembangkan.

Penelitian kali ini menggunakan model penelitian ADDIE yang terdiri dari 5 tahapan, namun pada tahap implementation dan tahap evaluation tidak dilaksanakan dikarenakan situasi dunia sedang dalam masa pandemic covid-19. Tahap yang pertama yakni tahap analyze (analisis). Pada tahap ini dilaksanakan beberapa analisis yakni analisis kebutuhan, analisis kurikulum, buku guru dan buku siswa, analisis karakteristik siswa, analisis syarat pembuatan media. Berdasarkan analisis kebutuhan yang dilakukan dengan metode wawancara dan kegiatan observasi pada kegiatan PLPbD 2020 di SD Negeri 3 Munduk Temu, diperoleh hasil bahwa diperlukannya pengembangan sebuah media pembelajaran karena dalam pelaksanaan pembelajaran ketersediaan media pembelajaran inovatif masih sangat minim. Hasil yang diperoleh pada analisis kurikulum adalah rumusan KD serta indikator dari materi pada media pembelajaran yang akan dikembangkan. Rumusan KD serta indikator dapat dilihat pada Tabel 6.

Tabel 6. Penjabaran KD dan Indikator Topik Struktur dan Fungsi Bagian Tumbuhan

\section{Kompetensi Dasar (KD)}

3.8 Memahami pentingnya upaya keseimbangan

dan pelestarian sumber daya alam di lingkungan
Indikator

3.8.1 Membuat gambar struktur bagian tumbuhan. 3.8.2 Menjelaskan struktur dan fungsi bagian 
tumbuhan.

3.8.3 Mengkritik upaya pelestarian sumber daya alam di lingkungan.

Dimodifikasi dari (Pratama et al., 2020)

Berdasarkan analisis karakteristik siswa yang dilakukan, diperoleh hasil bahwa siswa kelas IV sekolah dasar berada pada masa perkembangan operasional konkret. Sedangkan untuk tahapan analisis yang terakhir yakni analisis syarat pembuat media, diperoleh hasil berupa aspek-aspek yang harus diperhatikan dalam pembuatan media. Aspek-aspek tersebut teridri dari warna, font, layout, waktu, audio, dan backsound atau musik. Tahap kedua yakni design (perancangan), tahap ini menghasilkan rancangan awal pembuatan media pada storyboard (mohon maaf Bapak/Ibu, apabila rancangan awalya dimasukkan ke dalam jurnal halamannya lebih dari 12). Tahap ketiga yakni development (pengembangan), pada tahap telah menghasilkan media pembelajaran VideoScribe-HOTS berdasarkan rancangan dan storyboard yang telah dikonsultasikan dan mendapat kritik/saran dari dosen pembimbing. Beberapa masukan yang diterima antara lain durasi saat memaparkan KD, Indikator, dan Tujuan Pembelajaran terlalu cepat, tujuan gunakan format ABCD kurang degree dan gambar jenis akar diperbesar, 1 slide cukup 2 jenis akar. Setelah mengalami proses revisi, media pembelajaran yang telah berhasil dikembangkan dapat dilihat pada Gambar 3.

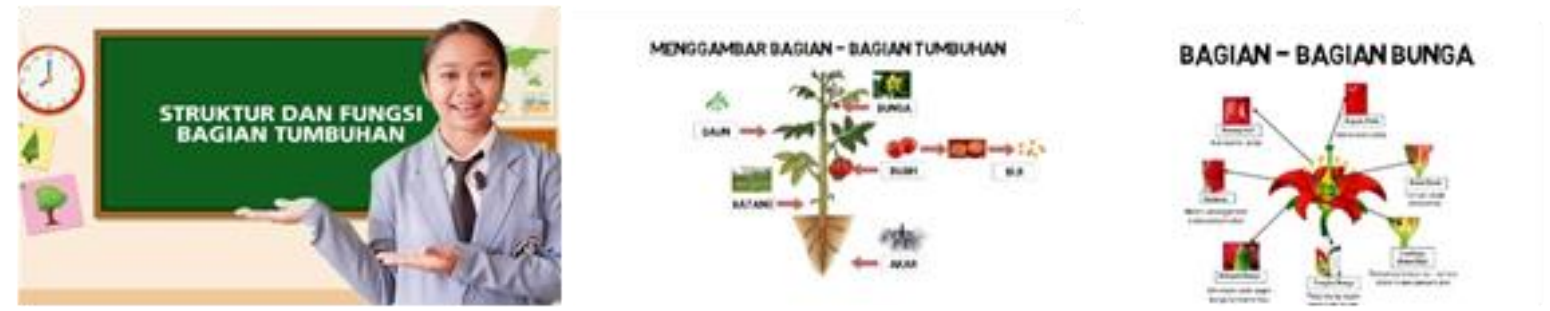

Gambar 3. Hasil Pengembangan Media

Berdasarkan uji validitas oleh ahli materi, ahli media, dan ahli desain pembelajaran di dapatkan hasil bahwa rentangan Indeks Validitas Aiken's adalah 0,8 - 1 yang berada pada $V \geq 0,8$ dengan kriteria validitas tinggi, respon praktisi sebesar 97\% berkategori sangat baik, dan respon siswa sebesar 97\% berkategori sangat baik. Maka dari itu dapat disimpulkan bahwa media pembelajaran VideoScribe-HOTS Pada Muatan Pelajaran IPA Topik Struktur dan Fungsi Bagian Tumbuhan dapat dinyatakan Valid.

\section{Pembahasan}

Penelitian ini merupakan penelitian pengembangan yaitu berupa pengembangan media pembelajaran VideoScribe-HOTS pada muatan pelajaran IPA topik Struktur dan Fungsi Bagian Tumbuhan. Model yang digunakan dalam penelitian ini yaitu model ADDIE yang terdiri dari lima tahapan yaitu analisis (analyze), perancangan (design), pengembangan (development), implementasi (implementation), dan evaluasi (evaluation). Model ADDIE merupakan suatu model yang menekankan pada adanya hubungan antara masing-masing komponen yang saling berinteraksi satu sama lain sesuai dengan fase yang ada (Atmojo et al., 2020; Wilujeng et al., 2020). Pemilihan model ini didasarkan pada tujuan dari penelitian yang dilakukan yaitu menghasilkan suatu produk berupa media pembelajaran VideoScribeHOTS. Produk yang dikembangakan kemudian diuji validitasnya sehingga mampu digunakan dalam pembelajaran untuk membantu meningkatkan motivasi dan semangat belajar siswa serta meningkatkan pemahaman siswa mengenai materi yang dijelaskan. Kelebihan penelitian ini yaitu terdapat pada desain produk yang dikembangkan dilengkapi dengan opsi menu dihalaman awal yang memudahkan peserta didik untuk memilih pembelajaran yang dinginkan.

Tahapan penelitian dengan menggunakan model ADDIE terdiri atas 4 tahapan namun hanya dilaksanakan sampai tahap pengembangan (development) saja dikarenakan keterbatasan waktu dan kondisi sedang masa pandemi Covid-19. Tahap pertama yaitu tahap analisis (analyze), pada tahap ini dilakukan analisis kebutuhan, analisis karakteristik siswa, analisis kurikulum, analisis buku guru dan buku siswa dan analisis syarat pembuatan media (Setiyani et al., 2020; Wilujeng et al., 2020). Berdasarkan penelitian yang telah dilakukan pada tahap analisis ini didapat hasil bahwa materi pada muatan pelajaran IPA yang ada pada buku siswa masih kurang lengkap dan perlu dikembangkan. Materi pada muatan pelajaran IPA topik Struktur dan Fungsi Bagian Tumbuhan dalam buku siswa masih perlu dikembangkan. Selain itu kurangnya kreativitas guru dalam mengembangkan media pembelajaran dalam kegiatan 
pembelajaran daring. Hal tersebut diakibatkan karena kurangnya sarana dan prasarana pendukung, kurangnya wawasan guru mengenai media pembelajaran, pembuatan media pembelajaran yang cukup lama, dan memerlukan keahlian dalam menggunakan teknologi. Oleh sebab itu, dilaksanakan pengembangan media pembelajaran VideoScribe-HOTS pada muatan pelajaran IPA topik struktur dan fungsi bagian tumbuhan kelas IV.

Tahap kedua yaitu tahap perancangan (design), merupakan tahapan membuat rancangan awal media pembelajaran VideoScribe-HOTS Pada Muatan Pelajaran IPA yang dimulai dengan menentukan Kompetensi Dasar (KD) dan Indikator Pencapaian Kompetensi pada topik Struktur dan Fungsi Bagian Tumbuhan Kelas IV, kemudian menyusun rancangan awal media pembelajaran VideoScribe-HOTS dan membuat Storyboard (Nahdi \& Jatisunda, 2020; Sutiarso et al., 2018). Setelah rancangan tersebut selesai, tahap selanjutnya yaitu melakukan bimbingan dengan dosen pembimbing guna mendapatkan kritik dan saran yang membangun mengenai media pembelajaran yang dibuat. Setelah rancangan tersebut disetujui, tahap selanjutnya yaitu membuat produk. Produk yang telah selesai dibuat kembali dilakukan bimbingan dengan dosen pembimbing. Setelah produk tersebut disetujui oleh dosen pembimbing, maka dapat dilanjutkan pada tahap selanjutnya yaitu tahap pengembangan (development). Tahap ketiga yaitu pengembangan (development) merupakan tahapan pengembangan produk yang telah dibuat. Produk yang telah dibuat dan mendapatkan persetujuan oleh dosen pembimbing kemudian diuji validitasnya untuk mengetahui tingkat validitas media pembelajaran yang dikembangkan (Arshad et al., 2021; Diningrat et al., 2020). Uji validitas yang dilakukan melibatkan 2 orang ahli materi IPA, 2 orang ahli media, 2 orang ahli desain pembelajaran, 2 orang guru sebagai praktisi dan 10 orang siswa kelas IV SD untuk respon siswa (kelompok kecil).

Berdasarkan hasil analisis data yang diperoleh, dapat disimpulkan bahwa media pembelajaran VideoScribe-HOTS memiliki Validitas Sangat Baik dan layak untuk digunakan oleh guru dan siswa dalam kegiatan pembelajaran baik itu dalam pembelajaran daring maupun luring. Hal tersebut dikarenakan media pembelajaran yang dikembangkan telah diukur berdasarkan kriteria yaitu pemilihan warna yang tepat digunakan dalam konten, pemilihan font huruf yang sesuai dengan konten, pemilihan layout yang sesuai dengan konten, menentukan durasi waktu yang tepat, menambahkan suara narasi yang sesuai dengan konten, dan menentukan musik yang sesuai dengan konten. Selain itu kelayakan media pembelajaran juga didasarkan pada kesesuaian dengan karakteristik siswa kelas IV. Hal ini di dukung oleh penelitian yang menyatakan bahwa media pembelajaran Sparkol VideoScribe berbasis CTL yang dikembangkan layak digunakan berdasarkan hasil penilaian dari ahli media diperoleh persentase sebesar 90\% dengan kriteria sangat layak dan hasil penilaian ahli materi diperoleh persentase sebesar 96,25\% dengan kriteria sangat layak (Adriyanto et al., 2021; Riyanto et al., 2019). Serta penelitian yang menyatakan bahwa terdapat pengaruh positif pada pembelajaran IPA yang menggunakan media video dibandingkan dengan pembelajaran IPA yang menggunakan media gambar terhadap motivasi belajar dan hasil belajar kognitif pembelajaran IPA (Gowasa et al., 2019; Jumareng \& Setiawan, 2021). Implikasi penelitian pengembangan yang dilakukan yaitu dengan adanya pengembangan media pembelajaran VideoScribe-HOTS ini diharapkan mampu membantu guru dalam menyampaikan materi pelajaran khususnya pada muatan pelajaran IPA topik struktur dan fungsi bagian tumbuhan kelas IV. Diketahui bahwa materi IPA merupakan salah satu materi yang tidak hanya dapat dijelaskan secara lisan saja namun juga perlu adanya melakukan praktik atau menampilkan benda konkret secara langsung agar siswa lebih mudah memahami materi yang dijelaskan. Adapun kekurangan penelitian ini adalah terkendalanya pelaksanaan kegiatan evaluasi yang diakibatkan keadaan dunia yang sedang dilanda pandemic covid-19. Saran bagi peneliti lain, penelitian ini dapat dijadikan bahan referensi dan jika memungkinkan dapat dilaksanakan sampai pada tahap evaluasi.

\section{SIMPULAN}

Media yang dikembangkan layak digunakan dengan kategori validitas sangat baik. Sehingga media pembelajaran Videoscribe-HOTS bermuatan IPA pada topik struktur dan fungsi bagian tumbuhan dijadikan referensi dalam mengatasi permasalahan kurangnya media inovatif yang berdampak pada rendahnya minat belajar serta literasi siswa ketika mengikuti proses pembelajaran.

\section{DAFTAR PUSTAKA}

Adi, Y. K., \& Widodo, A. (2018). Pemahaman Hakikat Sains Pada Guru Dan Siswa Sekolah Dasar. Edukasi Journal, 10(1), 55-72. https://doi.org/10.31603/edukasi.v10i1.1831.

Adriyanto, A. R., Santosa, I., Syarief, A., \& Irfansyah. (2021). Design and multimedia learning principles on 
mooc indonesiax. Cakrawala Pendidikan, 40(1), 92-106. https://doi.org/10.21831/cp.v40i1.34699.

Angraini, R. (2017). Karakteristik Media Yang Tepat Dalam Pembelajaran Pendidikan Kewarganegaraan (Pkn) Sebagai Pendidikan Nilai. Journal of Moral and Civic Education, 1(1), 14-24. https://doi.org/10.24036/8851412020171116.

Arshad, A. M., Halim, L., \& Nasri, N. M. (2021). Impact of integrating science and engineering teaching approach on students' achievement: A meta analysis. Jurnal Pendidikan IPA Indonesia, 10(2), 159170. https://doi.org/10.15294/jpii.v10i2.29839.

Atmojo, S. E., Muhtarom, T., \& Lukitoaji, B. D. (2020). The level of self-regulated learning and selfawareness in science learning in the covid-19 pandemic era. Jurnal Pendidikan IPA Indonesia, 9(4), 512-520. https://doi.org/10.15294/jpii.v9i4.25544.

Diningrat, S. W. M., Nindya, M. A., \& Salwa. (2020). Emergency online teaching: Early childhood education lecturers' perception of barrier and pedagogical competency. Cakrawala Pendidikan, 39(3), 705719. https://doi.org/10.21831/cp.v39i3.32304.

Friman, S. R. R. (2020). Pembelajaran Online di Tengah Pandemi Covid-19. Indonesian Journal of Educational Science, 02(02), 81-89. https://doi.org/10.31605/ijes.v2i2.659.

Gowasa, S., Harahap, F., \& Suyanti, R. D. (2019). Perbedaan Penggunaan Media Powerpoint dan Video Pembelajaran terhadap Kemampuan Berpikir Tingkat Tinggi dan Retensi Memori Siswa pada Mata Pelajaran IPA di Kelas V Sd. Jurnal Tematik, 9(1), 19-27. https://doi.org/10.24114/jt.v9i1.12859.

Haryani, S., Prasetya, A. T., \& Bahron, H. (2017). Building the character of pre-service teachers through the learning model of problem-based analytical chemistry lab work. Jurnal Pendidikan IPA Indonesia, 6(2), 229-236. https://doi.org/10.15294/jpii.v6i2.10688.

Irmansyah, J., Lumintuarso, R., Sugiyanto, F. X., \& Sukoco, P. (2020). Children's social skills through traditional sport games in primary schools. Cakrawala Pendidikan, 39(1), 39-53. http://dx.doi.org/10.21831/cp.v39i1.28210.

Jampel, I. N., Fahrurrozi, Artawan, G., Widiana, I. W., Parmiti, D. P., \& Hellman, J. (2018). Studying natural science in elementary school using nos-oriented cooperative learning model with the NHT type. Jurnal Pendidikan IPA Indonesia, 7(2), 138-146. https://doi.org/10.15294/jpii.v7i2.9863.

Jumareng, H., \& Setiawan, E. (2021). Self-esteem, adversity quotient and self-handicapping: Which aspects are correlated with achievement goals? Cakrawala Pendidikan, 40(1), 147-157. https://doi.org/10.21831/cp.v40i1.37685.

Jundu, R., Nendi, F., Kurnila, V. S., Mulu, H., Ningsi, G. P., \& Ali, F. A. (2020). Pengembangan Video Pembelajaran Ipa Berbasis Kontekstual Di Manggarai Untuk Belajar Siswa Pada Masa Pandemic Covid-19. LENSA (Lentera Sains): Jurnal Pendidikan IPA, 10(2), 63-73. https://doi.org/10.24929/lensa.v10i2.112.

Kurniawan, D. C., Kuswandi, D., \& Arafah Husna. (2018). Pengembangan Media Video Pembelajaran Pada Mata Pelajaran IPA Tentang Sifat Dan Perubahan Wujud Benda Kelas IV SDN Merjosari 5 Malang. JINOTEP (Jurnal Inovasi Dan Teknologi Pembelajaran), 4(2), 119-125. http://dx.doi.org/10.17977/um031v4i22018p119.

Latifah, N., Hasan, N., \& Fitria, Y. A. (2020). Pengembangan Media Pembelajaran Sparkol Videoscribe Terhadap Keterampilan Menulis Siswa Kelas Vi Sekolah Dasar Negri Sukamurni 1 Kabupaten Tengerang. Jurnal Madrasah $\quad$ Ibtidaiyah, 6(1), 40-48. http://dx.doi.org/10.31602/muallimuna.v6i1.3463.

Marlina, R., Puspaningrum, H., \& Hamdani. (2017). Differentiation of test items between the high school biology olimpiad in north kayong and the national science olimpiad. Jurnal Pendidikan IPA Indonesia, 6(2), 245-251. https://doi.org/10.15294/jpii.v6i2.10679.

Mayub, A., Suryani, E., \& Farid, M. (2020). Implementation of discovery learning model based on calor characteristic bricks mixed by (Durio zibethinus) and coconut (cocos nucifera) skin to improve students' cognitive learning outcomes. Jurnal Pendidikan IPA Indonesia, 9(2), 287-293. https://doi.org/10.15294/jpii.v9i2.23803.

MS, B., Rahmawati, S., \& Wardani, S. (2017). The Development of A Learning Media for Visualizing the Pancasila Values Based on Information and Communication Technology. Jurnal Cakrawala Pendidikan, 36(3), 502-521. http://dx.doi.org/10.21831/cp.v36i3.12748.

Mutia, R., Adlim, \& Halim, A. (2018). Pengembangan Video Pembelajaran Ipa Pada Materi Pencemaran Dan Kerusakan Lingkungan. Jurnal Pendidikan Sains Indonesia, 5(2), 110-116. https://doi.org/10.24815/jpsi.v5i2.9825.

Nahdi, D. S., \& Jatisunda, M. G. (2020). Analisis Literasi Digital Calon Guru Sd Dalam Pembelajaran Berbasis Virtual Classroom Di Masa Pandemi Covid-19. Jurnal Cakrawala Pendas, 6(2), 116-123. 
http://dx.doi.org/10.31949/jcp.v6i2.2133.

Nanda, K. K., Tegeh, I. M., \& Sudarma, I. K. (2017). Pengembangan Video Pembelajaran Berbasis Pendekatan Kontekstual Kelas V Di Sd Negeri 1 Baktiseraga. Jurnal Edutech Universitas Pendidikan Ganesha, 5(1), 88-99. http://dx.doi.org/10.23887/jeu.v5i1.20627.

Novita, L., Sukmanasa, E., \& Pratama, M. Y. (2019). Penggunaan Media Pembelajaran Video terhadap Hasil Belajar Siswa SD. Indonesian Journal of Primary Education, 3(2), 64-72. https://ejournal.upi.edu/index.php/IJPE/article/view/22103.

Pagarra, H., \& Idrus, N. A. (2018). Pengaruh Penggunaan Video Pembelajaran IPA Terhadap Minat Belajar Siswa Kelas III SD Inpres Lanraki 2 Kecamatan Tamalanrea Kota Makassar. Publikasi Pendidikan, 8(1), 30. https://doi.org/10.26858/publikan.v8i1.4362.

Pebriani, C. (2017). Pengaruh penggunaan media video terhadap motivasi dan hasil belajar kognitif pembelajaran IPA kelas V. Jurnal Prima Edukasia, 5(1), 11-21. https://doi.org/10.21831/jpe.v5i1.8461.

Pratama, I. G. D. J., Dantes, N., \& Yudiana, K. (2020). Thematic Learning Plan With A Nature Of Science Learning Model In The Fourth Grade Of Elementary School. International Journal of Elementary Education, 4(4), 447-453. https://ejournal.undiksha.ac.id/index.php/IJEE/article/view/27208.

Purnami, W., Ashadi, Suranto, Sarwanto, Sumintono, B., \& Wahyu, Y. (2021). Investigation of Person Ability and Item Fit Instruments of Eco Critical Thinking Skills in Basic Science Concept Materials for Elementary Pre-Service Teachers. Jurnal Pendidikan IPA, 10(1), 127-137. https://doi.org/10.15294/jpii.v10i1.25239.

Rapi, N. K. (2016). Pengaruh Model Pembelajaran Dan Jenis Penilaian Formatif Terhadap Hasil Belajar Ipa Siswa SMPN. Cakrawala Pendidikan, 1, 69-79. http://dx.doi.org/10.21831/cp.v1i1.8366.

Riyanto, M., Jamaluddin, U., \& Pamungkas, A. S. (2019). Pengembangan Video Pembelajaran Berbasis Aplikasi Video Scribe Pada Mata Pelajaran IPS di Sekolah Dasar. Madrasah, 11(2), 53-63. https://doi.org/10.18860/madrasah.v11i2.6419.

Rosana, D., Ramadani, M., \& Dewi, K. (2017). The Instrument for Assessing the Performance of Science Process Skills Based on Nature of Science (NOS). Jurnal Cakrawala Pendidikan, 36(3), 435-445. http://dx.doi.org/10.21831/cp.v36i3.14731.

Rusydiyah, E. F., Indrawati, D., Jazil, S., Susilawati, \& Gusniwati. (2021). Stem learning environment: Perceptions and implementation skills in prospective science teachers. Jurnal Pendidikan IPA Indonesia, 10(1), 138-148. https://doi.org/10.15294/jpii.v10i1.28303.

Setiawan, A., Widjaja, S. U. M., Kusumajanto, D. D., \& Wahyono, H. (2020). The effect of curriculum 2013 on economics learning achievement: Motivation as mediating variable. Cakrawala Pendidikan, 39(2), 444-459. http://dx.doi.org/10.21831/cp.v39i2.30279.

Setiyani, Putri, D. P., Ferdianto, F., \& Fauji, S. H. (2020). Designing a digital teaching module based on mathematical communication in relation and function. Journal on Mathematics Education, 11(2), 223-236. https://doi.org/10.22342/jme.11.2.7320.223-236.

Sutiarso, S., Coesamin, M., \& Nurhanurawati. (2018). The effect of various media scaffolding on increasing understanding of students' geometry concepts. Journal on Mathematics Education, 9(1), 95-102. /https://doi.org/10.22342/jme.9.1.4291.95-102.

Wilujeng, I., Tadeko, N., \& Dwandaru, W. S. B. (2020). Website-based technological pedagogical and content knowledge for learning preparation of science teachers. Cakrawala Pendidikan, 39(3), 545-559. https://doi.org/10.21831/cp.v39i3.31228.

Yudiyanto, Y., Hakim, N., Hayati, D. K., \& Carolina, H. S. (2020). Pengembangan Video Pembelajaran IPA Terpadu pada Tema Konservasi Gajah Berkarakter Peduli Lingkungan. Journal of Natural Science and Integration, 3(2), 187. https://doi.org/10.24014/jnsi.v3i2.8959.

Yustina, \& Kapsin. (2017). The implementation of constructivism-based student worksheets within the theme 'the prevention of land and forest fire' in science education for seventh graders in Riau. Jurnal Pendidikan IPA Indonesia, 6(2), 298-305. https://doi.org/10.15294/jpii.v6i2.10573.

Yusup, F. (2018). Uji Validitas dan Reliabilitas Instrumen Penelitian Kuantitatif. Jurnal Ilmiah Kependidikan, 7(1), 17-23. https://dx.doi.org/10.18592/tarbiyah.v7i1.2100. 